\title{
ESTIMATION OF DENSITY, MOISTURE CONTENT AND STRENGTH PROPERTIES OF Tectona grandis WOOD USING NEAR INFRARED SPECTROSCOPY
}

\author{
Shri Ram Shukla ${ }^{1, \star}$ \\ https://orcid.org/0000-0001-8341-226X
}

Suman Kumar Sharma ${ }^{1}$

\begin{abstract}
Near infrared spectroscopy is non-invasive and may be applied as a rapid and cost effective technique for assessment of quality parameters of timber. Near infrared spectra of Tectona grandis (teak) wood samples were collected before measuring physical (density, equilibrium moisture content) and strength (flexural and compressive) properties using conventional methods. Partial least squares regression was used to develop calibration models between measured wood properties and near infrared data. The best near infrared spectra pre-processing methods differed by property. Linear calibration models with high $\mathrm{R}^{2}$, low error and high ratio of performance to deviation values were observed from partial least squares analysis for different wood properties. These linear models may be applied for rapid and precise estimation of the properties examined in testing and evaluation procedures for commercially valuable teak wood.
\end{abstract}

Keywords: Calibration models, compression properties, density, equilibrium moisture content, flexural properties, NIRS, timber

\section{INTRODUCTION}

The original impetus for research in non-destructive testing and evaluation (NDT\&E) of wood is to provide methodologies for assessing quality parameters so that more accurate decisions can be made about rational utilization of this resource. The marketplace has become increasingly global and shipment of timber and wood products between countries is commonplace. In recent years, near infrared spectroscopy (NIRS) has become more common in many sectors as it meets the criteria of being rapid, accurate, reliable, non-destructive and inexpensive (Burns and Ciurczak 2007). It has also gained wide acceptance within many industries such as pulp and paper, pharmaceutical, food etc. for raw material testing, product quality control and process monitoring (Prieto et al. 2017, Roggo et al. 2007, Schwanninger et al. 2011, Tsuchikawa and Kobori 2015, Tsuchikawa and Schwanninger 2013, Williams 2001).

Research on using NIRS technique in the area of wood, wood composites and their products has been carried out only by a few research groups. Schimleck et al. (2000) reviewed applications of NIR spectroscopy as a rapid and inexpensive method for assessing the pulp quality from eucalypts. So et al. (2004) discussed about rapid assessment of solid wood properties using NIR spectra. NIRS in association with multivariate analysis techniques were also used to predict various wood quality parameters (Kelley et al. 2004, Mora and Schimleck 2009, Schimleck and Evans 2002, Schimleck et al. 2001, Tsuchikawa et al. 2005). Bailleres and Durand (2000) evaluated the wood quality of plantation-grown teak (Tectona grandis) using several non-destructive techniques. Naimeke et al. (2014) reported rapid prediction of phenolic compounds as chemical markers for the natural durability of teak heartwood by near infrared spectroscopy. Kokutse et al. (2010) estimated the 
dimensional stability of teak wood using NIRS and described that inclusion of additional samples may lead to stronger prediction models to be used on a wide range of woods of different plantation origins. They presented that the best prediction models may be applied for shrinkage screening and prediction of fibre saturation point of teak wood. Via et al. (2005) investigated the ability of NIR spectroscopy to monitor air-dry density distribution and its variation in wood. Tsuchikawa and Siesler (2003) also reported that NIRS is quite useful for estimating wood quality parameters with acceptable accuracy.

Economical utilization of available timber resources calls for a vast range of basic studies including techno-mechanical properties of wood. Teak is one of the most sought-after timbers known worldwide (FAO 2015). In tropical regions, teak is a very important and highly-valued hardwood due to its excellent wood quality, the attractiveness due to its grain and texture, high strength to weight ratio, and high durability of its heartwood against biological attack (Anda 2019, Tewari 1999). Teak is also easy to work and process without appearance of defects. Multiple ends uses of teak include building and construction, furniture and cabinets, parquet flooring, joinery, ship and vehicle body building, decorative veneer, reconstituted products, among others (Pandey and Brown 2000, Tewari 1999). Despite being a high value timber, its demand is increasing in domestic markets. As a result, teak is being imported from different countries (FAO 2015). Authenticity of species and wood quality parameters of such imported timbers is of concern. Hence, quick and non-destructive procedures may be developed for estimating various wood properties and species confirmation. Not many studies have been reported on using NIRS for rapid estimation of wood quality parameters of teak (Bailleres and Durand 2000, Kokutse et al. 2010, Naimeke et al. 2014). The aim of the present study was to develop the calibration models based on NIRS data for rapid and precise estimation of various important wood quality parameters of teak such as density, moisture content and strength properties.

\section{MATERIALS AND METHODS}

\section{Wood material}

Fifteen boards from different trees of teak (Tectona grandis L.f.) of the size $5 \mathrm{~cm}-6 \mathrm{~cm}$ (thickness), 30 $\mathrm{cm}-45 \mathrm{~cm}$ (width) and $180 \mathrm{~cm}-240 \mathrm{~cm}$ (length) were procured from a saw miller and imported teak supplier. The teak trees were originated from Myanmar (locally called Burma teak). A total of about 1200 wood specimens of different sizes were prepared for testing and evaluation of various physical and strength properties (BIS 1986).

\section{Physical properties}

\section{Density}

The specimen size was $20 \mathrm{~mm} \times 20 \mathrm{~mm}$ in cross-section and $60 \mathrm{~mm}$ in length. Total number of specimens was about 220 . The specimens were weighed correctly to $0,001 \mathrm{~g}$ and dimensions were measured correctly to $0,01 \mathrm{~mm}$. Volume of wood specimens was determined after immersing in water. Density of wood specimen was calculated using following Equation 1:

$$
\text { Density }=\frac{W_{1}}{V_{1}}
$$

Where $\mathrm{W}_{1}$ is weight $(\mathrm{kg})$ and $\mathrm{V}_{1}$ is the volume $\left(\mathrm{m}^{3}\right)$ of specimen at test condition.

\section{Equilibrium moisture content (EMC)}

All the specimens $20 \mathrm{~mm} \times 20 \mathrm{~mm} \times 25 \mathrm{~mm}$ were weighed initially with an accuracy of $0,001 \mathrm{~g}$. A set of about 48 small blocks were exposed to the eight saturated solutions of different salts in desiccators (Arabhosseini 2005). Weights of 5 samples were also recorded at regular intervals to monitor the changes in moisture uptake/release. Samples were kept in different desiccators for a period of about 4 months and equilibrated until the difference between two weights of individual wood block was less than $0,2 \%$ over two 
successive days. Once equilibrium was reached, wood blocks were taken out, kept in a small desiccator and NIR spectra were collected. Final weights of these samples were recorded after drying in an oven at $103^{\circ} \mathrm{C} \pm$ $2^{\circ} \mathrm{C}$ for $48 \mathrm{~h}$. The EMC of test samples was computed as Equation 2:

$$
\operatorname{EMC}(\%)=\frac{W_{1}-W_{0}}{W_{0}} \times 100
$$

Where $\mathrm{W}_{1}=$ weight of specimen at test $(\mathrm{g})$ and $\mathrm{W}_{0}=$ oven-dry weight of specimen $(\mathrm{g})$.

\section{Mechanical properties}

Flexural strength (modulus of rupture-MOR), stiffness (modulus of elasticity-MOE) and compressive strength parallel to grain (maximum crushing stress-MCS) as described in Indian standard (BIS 1986) were evaluated using $50 \mathrm{kN}$ universal testing machine (Model: AG-50, Shimadzu). Clear wood samples having perfect radial and tangential surfaces were selected for testing as described below:

\section{Flexural strength and stiffness}

Wood specimens for static bending were kept in a room for conditioning to $12 \% \pm 2 \%$ moisture content. The size of specimens was $20 \mathrm{~mm} \times 20 \mathrm{~mm} \times 300 \mathrm{~mm}$ with a span length of $280 \mathrm{~mm}$. Rate of loading was kept constant at $1,0 \mathrm{~mm} / \mathrm{min}$ and load was applied on the tangential surface. MOR and MOE were computed using following Equation 3a and Equation 3b:

$$
\begin{aligned}
& \text { MOR }=\frac{\left(3 * P_{\max } * l\right)}{\left(2 * b^{*} h^{2}\right)} \\
& \text { MOE }=\frac{\left(P^{*} l^{3}\right)}{\left(4 * D^{*} b^{*} h^{3}\right)}
\end{aligned}
$$

Where $\mathrm{P}=$ load $(\mathrm{kN})$, and $\mathrm{D}=$ deflection $(\mathrm{mm})$ at limit of proportionality; $\mathrm{P}_{\max }=\operatorname{maximum}$ load $(\mathrm{kN}) ; 1=$ span $(\mathrm{mm}), \mathrm{b}=$ breadth $(\mathrm{mm})$ and $\mathrm{h}=$ depth $(\mathrm{mm})$ of test specimen.

\section{Compressive strength parallel to grain}

Defect free test specimens $20 \mathrm{~mm} \times 20 \mathrm{~mm}$ in cross-section and $80 \mathrm{~mm}$ in length were selected. The ends were sanded perfectly at right angles to length. Specimen was placed such that center of movable head was vertically above the center of cross-section of specimen. During the testing, load was continuously applied at a constant rate of $0,6 \mathrm{~mm}$ per min. MCS was calculated by the Equation 4 :

$$
M C S=\frac{P^{\prime}}{A}
$$

Where $P^{\prime}=$ maximum load at break point $(\mathrm{kN}), A=$ area of cross-section of specimen $\left(\mathrm{mm}^{2}\right)$

\section{Measurement of NIR spectra}

A NIR spectrophotometer (MPA, Bruker Optics,) was used to collect diffuse reflectance NIR spectra of wood samples over the wavelength range $780 \mathrm{~nm}$ to $2500 \mathrm{~nm}\left(4000 \mathrm{~cm}^{-1}\right.$ to $\left.12820 \mathrm{~cm}^{-1}\right)$ with a resolution of $8 \mathrm{~cm}^{-1}$ using integrating sphere. Integrating sphere fitted with detector permits a direct measurement of large sample area (15 mm spot size). A total of 32 scans were collected for each position and total collected scans were averaged into a single spectrum to compensate for the natural variation present. For each surface, two 
spectra each from tangential longitudinal (TL) and radial longitudinal (RL) were collected, providing four positions per sample.

\section{Preprocessing of spectra and development of calibration models}

For spectral noise reduction and smoothing, raw spectra were subjected to pre-processing algorithms to convert into useful spectral information. For comparisons, different pre-processing techniques such as first derivative with multiplicative scattering correction (MSC), straight line subtraction (SLS) and standard normal variate (SNV) were the most appropriate treatment procedures for the models through an optimization procedure. When first and second derivatives were applied, spectra were smoothed and differentiated by applying the algorithm proposed by Savitzky and Golay (1964) using 17 smoothing points. Bruker OPUS 5.5 Quant package was used for optimization and model development. For other analysis and data plotting, SigmaStat (Version 3.5, Systat Software Inc.) and SigmaPlot (Version 10.0, Systat Software Inc.) software were used.

NIR spectral data with multivariate statistical modeling was used for analysis and estimation of wood properties. For spectral analysis and partial least squares (PLS) modeling, models developed for density, EMC and mechanical properties were validated and their robustness evaluated. Full cross-validation was used for validating the results and selecting the number of factors giving minimum residual variance using inbuilt algorithm of OPUS Quant package. Based on whole spectral range, a region of higher value of coefficient of estimation $\left(\mathrm{R}^{2}\right)$, cross-validation $\left(\mathrm{R}_{\mathrm{p}}{ }^{2}\right)$ and ratio of performance to deviation (RPD) between spectral data and wood property as well as lower values of root mean square errors of estimation (RMSEE) and cross-validation (RMSECV) were used for evaluation of PLS regression models. More than one pre-processing method gave good models; however, only the best calibrations are presented for each wood property.

\section{RESULTS AND DISCUSSION}

\section{Density}

The average wood density of teak was $622,20 \mathrm{~kg} / \mathrm{m}^{3} \pm 48,36 \mathrm{~kg} / \mathrm{m}^{3}$ at $12 \% \pm 2 \%$ moisture content. The coefficient of variation was $7,77 \%$ and density values ranged from $525,89 \mathrm{~kg} / \mathrm{m}^{3}$ to $805,20 \mathrm{~kg} / \mathrm{m}^{3}$. Unprocessed teak NIR spectra subjected to first derivative plus multiplicative scattering correction (MSC) algorithm (smoothing points 17) are shown respectively in Figure 1a and Figure 1b.
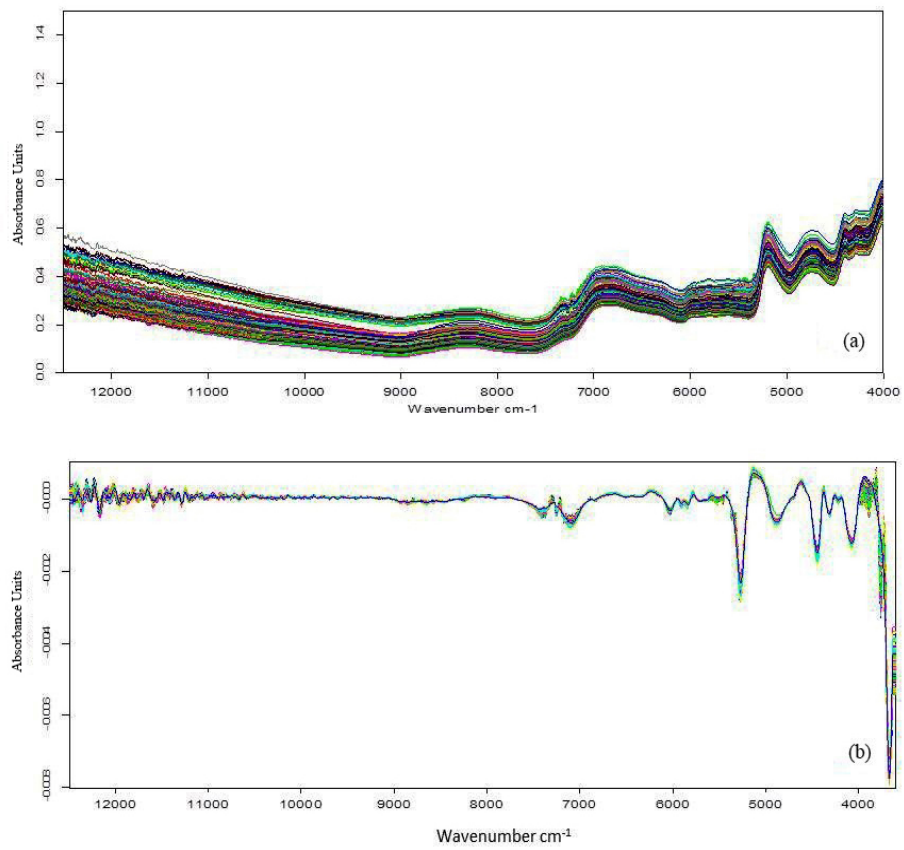

Figure 1: NIR spectra of density samples of teak wood (a), preprocessed spectra by First Derivative plus MSC (b). 
Table 1 summarizes PLS-R calibration model between measured wood density and NIR spectral data. Several pre-treatments were carried out using spectral ranges between $9000 \mathrm{~cm}^{-1}$ and $4000 \mathrm{~cm}^{-1}$ with optimization of model parameters. Figure 2 shows correlation between measured and NIR predicted density values. The calibration and validation sets have shown linear correlation with high values of $\mathrm{R}_{\mathrm{p}}^{2}$ between measured and NIR predicted density values and lower values of RMSECV. The optimum values of rank and RPD were 5,0 and 3,58 respectively. It may be noted that application of NIRS predictive models for forest science considers models having RPD values above 1,5 to be satisfactory for preliminary prediction (Schimleck et al. 2003).

Table 1: Summary of NIRS calibration of density, EMC, MOR, MOE and MCS of teak.

\begin{tabular}{|c|c|c|c|c|c|c|}
\hline $\begin{array}{c}\text { Wood } \\
\text { property }\end{array}$ & Preprocessing (Treatment) & $\begin{array}{l}\mathrm{R}^{2} \\
\left(\mathrm{R}_{\mathrm{p}}{ }^{2}\right)\end{array}$ & $\begin{array}{c}\text { Rank (Latent } \\
\text { variables) }\end{array}$ & $\begin{array}{l}\text { RMSEE } \\
(\mathrm{RMSCV})\end{array}$ & RPD & $\begin{array}{l}\text { Frequency band } \\
\qquad\left(\mathrm{cm}^{-1}\right)\end{array}$ \\
\hline $\begin{array}{l}\text { Density } \\
\left(\mathrm{kg} / \mathrm{m}^{3}\right)\end{array}$ & $\begin{array}{l}\text { First derivative }+ \text { MSC } \\
\text { (17 point })\end{array}$ & $\begin{array}{c}0,94 \\
(0,92)\end{array}$ & 5 & $\begin{array}{c}9,29 \\
(10,1)\end{array}$ & 3,58 & $\begin{array}{l}7502,5-5450,3 \\
4601,4-4247,8\end{array}$ \\
\hline $\begin{array}{l}\text { EMC } \\
(\%)\end{array}$ & MSC & $\begin{array}{c}0,97 \\
(0,96)\end{array}$ & 9 & $\begin{array}{c}0,48 \\
(0,51)\end{array}$ & 5,19 & $\begin{array}{l}7100,8-6398,8 \\
5303,4-4948,6\end{array}$ \\
\hline $\begin{array}{l}\text { MOR } \\
(\mathrm{MPa})\end{array}$ & Min-Max normalization & $\begin{array}{c}0,93 \\
(0,92)\end{array}$ & 6 & $\begin{array}{c}2,95 \\
(3,11)\end{array}$ & 3,54 & $7502-4598$ \\
\hline $\begin{array}{l}\mathrm{MOE} \\
(\mathrm{MPa})\end{array}$ & MSC & $\begin{array}{c}0,95 \\
(0,94)\end{array}$ & 5 & $\begin{array}{c}251,0 \\
(309,0)\end{array}$ & 3,94 & $\begin{array}{c}8192-6098,5454 \\
-4246,6\end{array}$ \\
\hline $\begin{array}{l}\text { MCS } \\
(\mathrm{MPa})\end{array}$ & SNV & $\begin{array}{c}0,96 \\
(0,95)\end{array}$ & 8 & $\begin{array}{c}1,38 \\
(1,43)\end{array}$ & 4,49 & $5453,8-4597,6$ \\
\hline
\end{tabular}

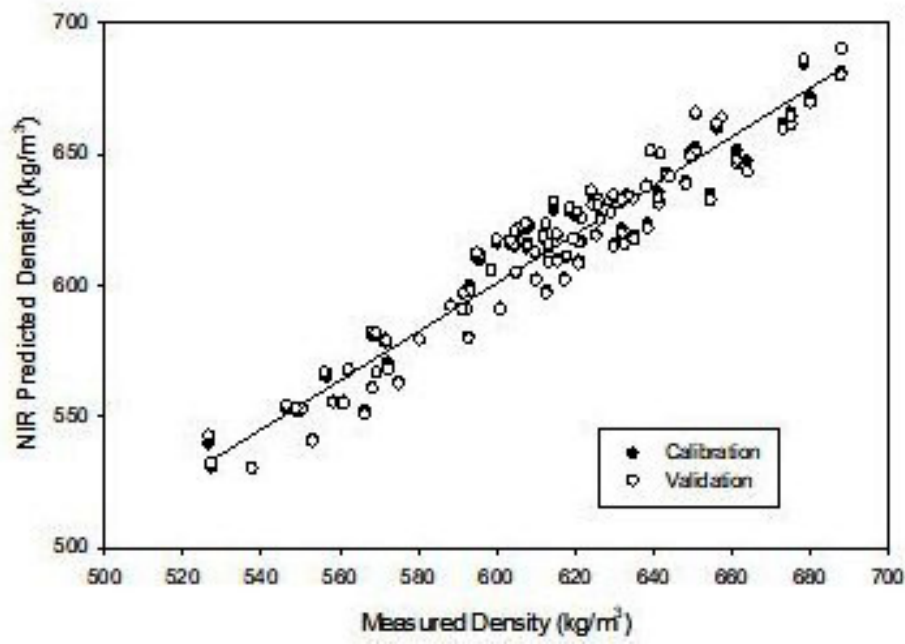

Figure 2: NIR predicted vs. measured (reference) density of teak wood.

As listed in Table 1, two optimum frquency ranges of $1333 \mathrm{~nm}-1835 \mathrm{~nm}$ and $2173 \mathrm{~nm}-2354 \mathrm{~nm}$ in combination gave the best models for air-dry density of teak. Many researchers have also used $1000 \mathrm{~nm}-2000$ $\mathrm{nm}$ and $1111 \mathrm{~nm}-2500 \mathrm{~nm}$ regions for developing the models (Carneiro et al. 2010). Fujimoto et al. (2012) used band positions of $7320 \mathrm{~cm}^{-1}, 7160 \mathrm{~cm}^{-1}$ and $7000 \mathrm{~cm}^{-1}$ for developing wood density models independent of moisture conditions of samples. Only a few researchers have used entire range of $12800 \mathrm{~cm}^{-1}$ to $4000 \mathrm{~cm}^{-1}$ for development of models for different wood properties (Hein et al. 2009a, Hein et al. 2009b). Robustness 
of models based on NIR spectra to predict basic density and other properties of E. urophylla was reported by Hein et al. (2010). Schimleck and Evans (2003) investigated air-dry density calibration of radiata pine using 5 factors. Mora et al. (2008) reported NIR calibration models for estimation of wood density in softwood using repeated measurements. Raturi et al. (2012) also applied this technique for prediction of specific gravity of dry E. tereticornis solid wood samples.

\section{EMC}

Figure 3 shows measured and NIR predicted EMC of teak for the calibration and predictions sets. The correlation coefficients and root mean square errors for the calibration and prediction sets were $(0,97 \%$; 0,48 $\%)$ and $(0,96 \% ; 0,51 \%)$ respectively.

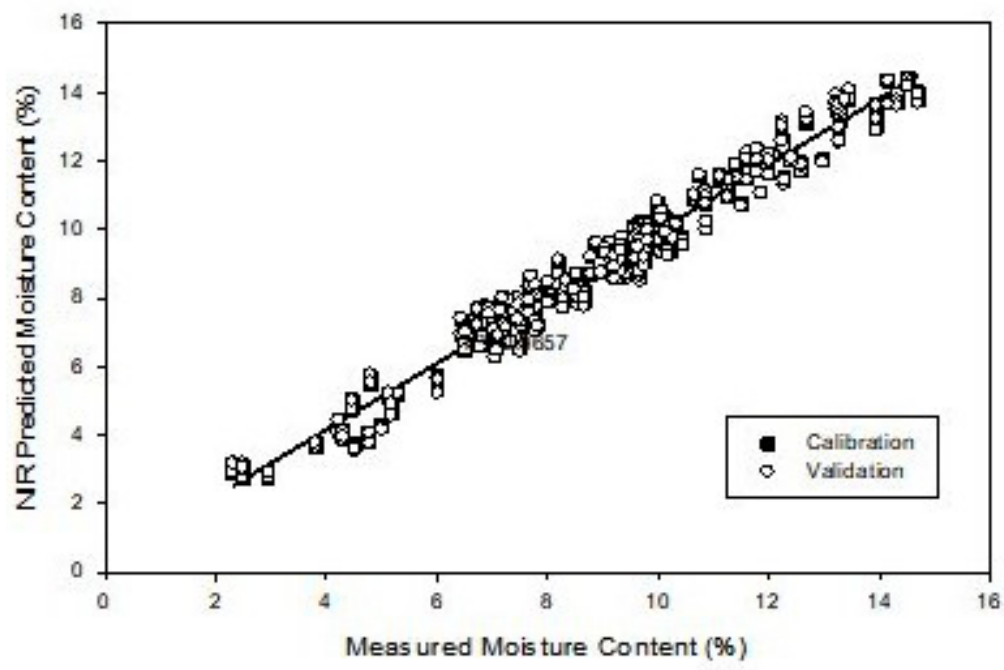

Figure 3: Measured vs. NIR predicted EMC of teak wood.

Development of model for EMC was carried out using PLS-R analysis between measured wood EMC values and NIR spectra. Different pre-processing methods were applied using different NIR spectral ranges between $9000 \mathrm{~cm}^{-1}$ and $4000 \mathrm{~cm}^{-1}$ with optimization of model parameters. Summary of NIRS calibration of EMC is shown in Table 1. Two frequency regions for optimum performance were $7100,8 \mathrm{~cm}^{-1}-6398,8 \mathrm{~cm}^{-1}$ and $5303,4 \mathrm{~cm}^{-1}-4948,6 \mathrm{~cm}^{-1}$. The wavenumbers above $9000 \mathrm{~cm}^{-1}$ and below $4000 \mathrm{~cm}^{-1}$ were avoided due to the low and high intensity of absorbance bands in these regions respectively.

Moisture content of wood plays an important role in the NIR spectrum and represented by several bands (Schwanninger et al. 2011). Absorption spectra of water have been resolved into component bands centered at $5200 \mathrm{~cm}^{-1}$ associated with water molecules. Hydroxyl groups are often involved in hydrogen bonding and $1 \mathrm{st}$ OT of O-H stretching depends on the strength of the hydrogen bonds, which is important for bands of cellulose. The band at $6944 \mathrm{~cm}^{-1}$ is assigned to free $\mathrm{O}-\mathrm{H}$ groups and bands at $6710 \mathrm{~cm}^{-1}$ and $6494 \mathrm{~cm}^{-1}$ to $\mathrm{H}$-bonded $\mathrm{O}-\mathrm{H}$ groups. Similarly, the absorption bands at $6770 \mathrm{~cm}^{-1}, 6945 \mathrm{~cm}^{-1}$ and $7073 \mathrm{~cm}^{-1}$ have been assigned to the $1^{\text {st }}$ overtone of cellulosic $\mathrm{O}-\mathrm{H}$, adsorption of water and water-water $\mathrm{H}$-bonds respectively. The band found at $5200 \mathrm{~cm}^{-1}$ is attributable to hydroxyl $(\mathrm{O}-\mathrm{H})$ and carbonyl $(-\mathrm{C}=\mathrm{O})$ groups, the band at $7000 \mathrm{~cm}^{-1}$ to hydroxyl groups (Schwanninger et al. 2011). Both are strongly influenced by the moisture present in the solid teak wood samples. The teak wood spectra indicated that the absorption bands with peak maxima around 4761 and 5924 $\mathrm{cm}^{-1}$ were associated with C-H and $\mathrm{O}-\mathrm{H}$ combination bands and 5880 and $4545 \mathrm{~cm}^{-1}$ overtones. Haddadi et al. (2016) also applied visible-NIRS technique to determine the moisture content of wood. A comprehensive review on using NIRS for monitoring the moisture content and density of solid wood is presented by Leblon $e t$ al. (2013). Defo et al. (2007) studied applicability and usefulness of NIRS in estimating the moisture content and density of fresh-sawn red oak wood. Cooper et al. (2011) reported that average moisture content of airdried wood can be estimated accurately within $\pm 2 \%$ to $5 \%$. 


\section{Mechanical properties}

\section{Flexural MOR}

Average values of MOR of teak along with standard deviation, COV and range (maximum, minimum) are listed in Table 2. Maximum-minimum algorithm was used for preprocessing treatment of the original spectra. Figure 4 shows measured vs. NIR predicted MOR for calibration and prediction sets. The optimum rank and RPD values were 7 and 3,54 respectively.

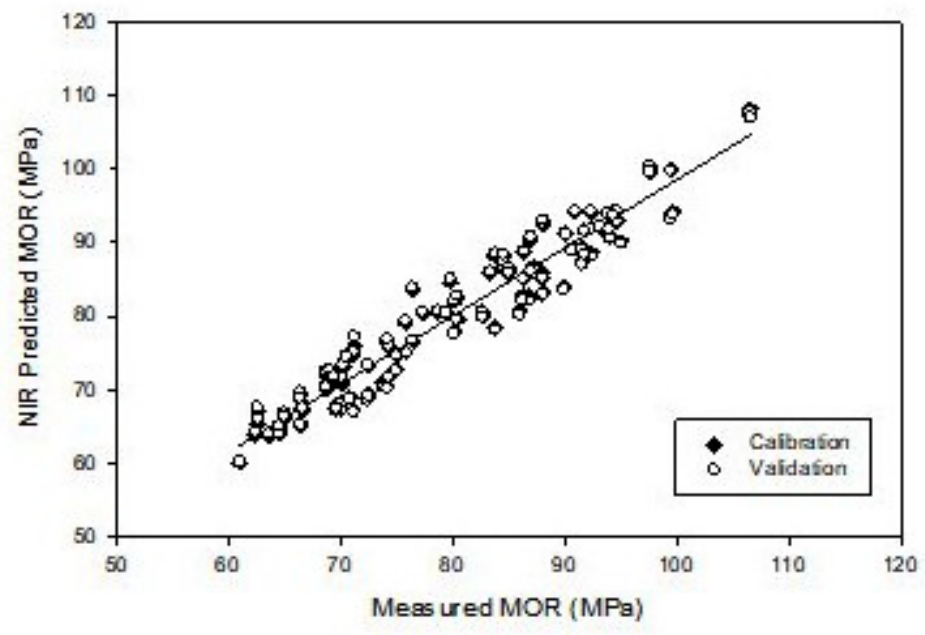

Figure 4: Measured vs. NIR predicted MOR of teak wood.

Table 2: Average values of MOR, MOE and MCS of teak wood.

\begin{tabular}{|c|c|c|c|c|c|c|}
\hline $\begin{array}{c}\text { Mechanical } \\
\text { property }\end{array}$ & $\begin{array}{c}\text { Number of } \\
\text { samples } \\
(\mathrm{N})\end{array}$ & $\begin{array}{c}\text { Average } \\
\text { value } \\
(\mathrm{MPa})\end{array}$ & $\begin{array}{c}\text { Standard } \\
\text { deviation } \\
(\mathrm{SD}, \mathrm{MPa})\end{array}$ & $\begin{array}{c}\text { Coefficient of } \\
\text { variation } \\
(\mathrm{COV}, \%)\end{array}$ & $\begin{array}{c}\text { Maximum } \\
\text { MOR } \\
(\mathrm{MPa})\end{array}$ & $\begin{array}{c}\text { Minimum } \\
\text { MOR } \\
(\mathrm{MPa})\end{array}$ \\
\hline MOR & 200 & 79,19 & 17,09 & 21,58 & 116,54 & 41,35 \\
\hline MOE & 200 & 10695,69 & 1935,44 & 18,10 & 25763,48 & 6560,64 \\
\hline MCS & 197 & 47,94 & 7,87 & 16,42 & 65,92 & 31,63 \\
\hline
\end{tabular}

Treatments with various pre-processing methods were carried out using different spectral ranges between $9000 \mathrm{~cm}^{-1}$ and $4000 \mathrm{~cm}^{-1}$ for optimization of model parameters. Table 1 also provides the summary of NIRS calibration analysis of MOR. Min-max pre-processing and wavenumbers in the range of $7502 \mathrm{~cm}^{-1}-4598 \mathrm{~cm}^{-1}$ were responsible for development of the best models for MOR. $\mathrm{R}_{\mathrm{n}}^{2}$, rank, RMSECV and RPD were 0,92 MPa, $6 \mathrm{MPa}, 3 \mathrm{MPa}, 11 \mathrm{MPa}$ and 3,54 MPa respectively for the best MOR calibration.

\section{Flexural MOE}

Summary of development of PLS regression models between measured MOE and NIR spectral data (pre-processed using MSC) is shown Table 1. Linear plots between measured and NIR predicted MOE for calibration and prediction sets are shown in Figure 5. 


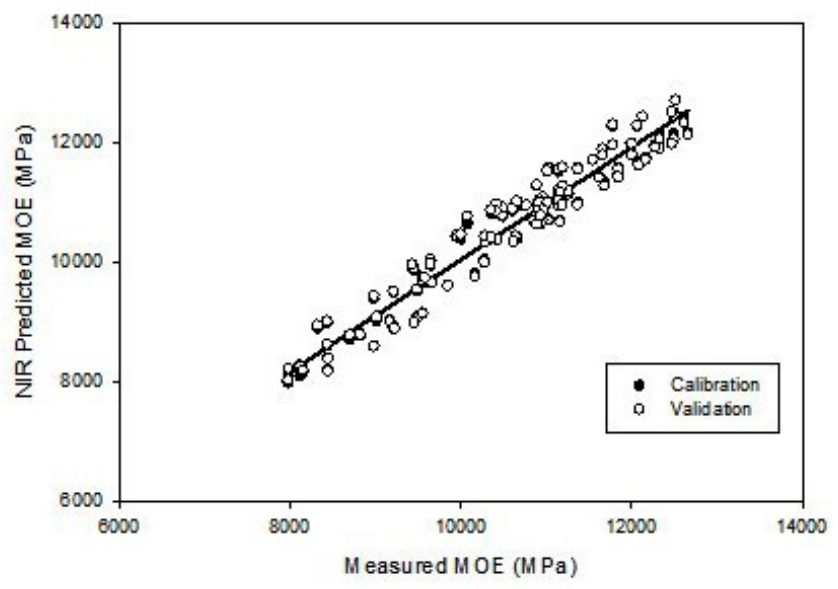

Figure 5: Measured vs. NIR predicted MOE of teak wood.

The pre-processing methods were applied using different spectral ranges between $9000 \mathrm{~cm}^{-1}$ and $4000 \mathrm{~cm}^{-1}$ to optimize the model parameters. Two frequency regions, $8192 \mathrm{~cm}^{-1}-6098 \mathrm{~cm}^{-1}$ and $5454 \mathrm{~cm}^{-1}-4246,6 \mathrm{~cm}^{-1}$ gave the best model for MOE. The optimum number of latent variables (rank) and RMSECV values were 5 $\mathrm{MPa}$ and 309,0 MPa respectively. Similarly, the best $\mathrm{R}_{\mathrm{p}}{ }^{2}$ and RPD values for MOE were found to be 0,94 and 3,94 respectively. NIRS and multivariate calibration technique was applied to predict the stiffness of Liriodendron tulipifera (Adedipe et al. 2008). Kothiyal and Raturi (2011) studied certain mechanical properties (MOR, MOE) of E. tereticornis wood samples using NIRS coupled with multivariate analysis. PLS-R calibrations models were developed showing good relationships between measured and predicted values. It is also reported that coefficient of determination for calibration and prediction ranged from 0,76-0,83 and 0,58-0,77 SEPs were slightly higher compared to SECs. Kelley et al. (2004) used NIRS to measure the mechanical properties (MOR and MOE in three-point bending) of solid loblolly pine wood. Gindl et al. (2001) reported the relationship between NIR spectra of radial surfaces and mechanical properties of wood. Andrade et al. (2010) applied NIRS technique to obtain calibrations for mechanical properties of E. urophylla hybrid. They reported that NIRS technique is suitable to estimate MOR in solid wood with high values of $r$ and RPD. MOR and compressive strength presented $\mathrm{R}$ values below 0,9 .

\section{MCS}

Average values along with standard deviation, COV and range of MCS of teak wood are listed in Table 2. After comparison of different pre-processing techniques, SNV was found to be the most appropriate treatment procedure for the MCS models. Figure 6 shows the plots between the measured and predicted MCS values for the calibration and prediction sets. Table 1 demonstrates the summary statistics for the best calibration model developed using PLS-R method between measured MCS and teak NIR spectra. Wavenumbers in the range of $5453,8 \mathrm{~cm}^{-1}-4597,6 \mathrm{~cm}^{-1}$ were found to be responsible for development of best models for MCS with $\mathrm{R}^{2}$ and RPD values of $95,05 \%$ and 4,49 respectively. Similarly, the number of latent variables (rank) and RMSECV were 8 and 1,43 MPa for best MCS calibration model. Hoffmeyer and Pedersen (1995) also estimated the compressive strength of Picea abies wood by using NIRS method. NIR calibrations for compression strength proved that the NIR technique is an excellent non-destructive method $\left(\mathrm{R}^{2} \geq 0,9 \%\right)$. The authors concluded that this method is very versatile in non-destructive evaluation of wood properties. Andrade et al. (2010) also reported the suitability of NIRS to estimate the compressive strength of $E$. urophylla hybrid with $\mathrm{R}<0,9 \%$. 


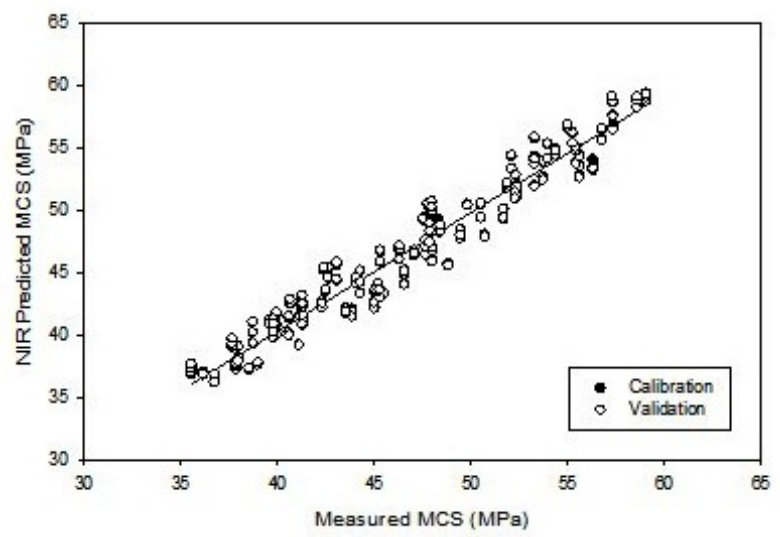

Figure 6: Measured vs. NIR predicted MCS of teak wood.

The strength properties of solid wood are generally related with the specific gravity, microfibril angle (MFA) and slope of grain (Butterfield 1997). Tsehaye et al. (1997) discussed a strong relationship between MOE and cellulose content. As NIR spectra of wood contain information on its different chemical constituents, its various properties such as specific gravity, MFA and cellulose content may be correlated (Kelley et al. 2004). Their results also showed that the strength properties of wood samples could be accurately predicted from the NIR spectra. Figure $1 \mathrm{~b}$ shows the $2^{\text {nd }}$ derivative of NIR spectra of teak wood where peaks are attributed to second overtones of hydroxyls and third overtones of $\mathrm{C}-\mathrm{H}$ stretching vibrations. The first overtone of cellulose and hemicellulose hydroxyls are observed between $7142,9 \mathrm{~cm}^{-1}$ and $6024,1 \mathrm{~cm}^{-1}$ (Kelley et al. 2004). Strong vibration at $4950,5 \mathrm{~cm}^{-1}$ to $4444,4 \mathrm{~cm}^{-1}$ has also been allocated to cellulose hydroxyl vibrations. The first overtone of the lignin and carbon/hydrogen vibrations have been visualized between $5479 \mathrm{~cm}^{-1}$ and $6116 \mathrm{~cm}^{-1}$ (Schwanninger et al. 2011). Some of the lignin hydroxyl vibrations were found to overlap with cellulose hydroxyl vibrations, e.g., first overtone of lignin hydroxyl vibrations occurs between $7142,9 \mathrm{~cm}^{-1}$ and $6578,9 \mathrm{~cm}^{-1}$. Michell and Schimleck (1996) assigned the bands at $5995 \mathrm{~cm}^{-1}, 5974 \mathrm{~cm}^{-1}$ and $5938 \mathrm{~cm}^{-1}$ in $2^{\text {nd }}$ derivative wood spectra to extractives and lignin. The bands near $4690 \mathrm{~cm}^{-1}$ and $5974 \mathrm{~cm}^{-1}$ were designated to 1st overtone of C-H from lignin. Similarly, Schwanninger et al. (2011) assigned the bands at $6003 \mathrm{~cm}^{-1}, 5950$ $\mathrm{cm}^{-1}, 5816 \mathrm{~cm}^{-1}$ and $5656 \mathrm{~cm}^{-1}$ to $1^{\text {st }}$ overtone of $\mathrm{C}-\mathrm{H}$ stretching vibrations from methyl groups derived from hemicelluloses in wood.

\section{CONCLUSIONS}

NIRS coupled with multivariate regression analysis (PLS-R) has been applied to develop calibration models for different physical and mechanical properties of teak. NIR spectra of teak wood samples were collected before measuring different properties using conventional methods. Linear models were developed between measured and NIRS estimated values of density, EMC, MOR, MOE and MCS. These predictive models may be applied for non-destructive and rapid evaluation of teak avoiding conventional destructive, time consuming and expensive test methods. However, such models and libraries are required to be strengthened continuously for more accurate and precise estimations of various wood properties of commercially valuable timber species.

\section{ACKNOWLEDGEMENTS}

Authors are thankful the Director, Group Coordinator (Research) and Head, Wood Properties and Uses Division, Institute of Wood Science and Technology, Bangalore for their keen interest in the research work. Valuable technical help from the division staff and project fellows is duly acknowledged. The authors are also thankful to ICFRE for providing financial support to complete the project No: IWST/WPEW/XI/155. 


\section{REFERENCES}

Adedipe, O.E.; Dawson-Andoh, B. 2008. Prediction of yellow-poplar (Liriodendron tulipifera) veneer stiffness and bulk density using near infrared spectroscopy and multivariate calibration. J Near Infrared Spec 16(5): 487-496. https://doi.org/10.1255/jnirs.812

Anda, R.R.; Koch, G.; Richter, H.G.; Talavera, F.J.F.; Guzan, J.A.S.; Satyanarayana, K.G. 2019. Formation of heartwood, chemical composition of extractives and natural durability of plantation grown teak wood from Mexico. Holzforschung 73(6): 547-557. https://doi.org/10.1515/hf-2018-0109

Andrade, C.R.; Trugilho, P.F.; Napoli, A.; Vieira R.S.; Lima, J.T.; Sousa, L.C. 2010. Estimation of the mechanical properties of wood from Eucalyptus urophylla using near infrared spectroscopy. Cerne 16(3): 291-298. http://dx.doi.org/10.1590/S0104-77602010000300005

Arabhosseini, A.; Huisman, W.; Boxtel, A.; Muller, J. 2005. Modeling of the equilibrium moisture content (EMC) of Tarragon (Artemisia Dracunculus L.). Int J Food Eng 1(5): 1-17. https://doi.org/10.2202/15563758.1025

Bailleres, H.; Durand, P.Y. 2000. Non-destructive techniques for wood quality assessment of plantation-grown teak. Bois For Trop 263: 17-29.

BIS. 1986. Method of testing small clear specimens of timber. BIS. IS 1708. Bureau of Indian Standards: New Delhi, India. 64p.

Burns, D.A.; Ciurczak, E.W. 2007. Handbook of Near-Infrared Analysis, $3^{\text {rd }}$ Edition. CRC Press: Boca Raton, FL, USA, 834p. https://www.crcpress.com/Handbook-of-Near-Infrared-Analysis/BurnsCiurczak/p/ book/9780849373930

Butterfield, B.G. 1997. Microfibril angle in wood. In Proceedings of the IAWA/IUFRO International Workshop on the Significance of Microfibril Angle to Wood Quality. Westport, New Zealand. International Association of Wood Anatomists. International Union of Forestry Research Organizations.

Carneiro, M.E.; Magalhaes, W.L.E.; Muniz, G.I.B.; Schimleck, L.R. 2010. Near infrared spectroscopy and chemometrics for predicting specific gravity and flexural modulus of elasticity of Pinus spp. veneers. J Near Infrared Spec 18(6): 481-489. https://www.osapublishing.org/jnirs/abstract.cfm?URI=jnirs-18-6-481

Cooper, P.A.; Jeremic, D.; Radivojevic, S.; Ung, Y.T.; Leblon, B. 2011. Potential of near-infrared spectroscopy to characterize wood products. Can J Forest Res 41(11): 2150-2157. https://doi.org/10.1139/x11-088

Defo, M.; Taylor, A.M.; Bond, B. 2007. Determination of moisture content and density of fresh-sawn red oak lumber by near infrared spectroscopy. Forest Prod J 57(5): 68-72. https://forestprod.org/page/FPJ\#

FAO. 2015. Global teak trade in the aftermath of Myanmar's log export ban' by Kollert, W.; Walotek, P.J., Planted Forests and Trees Working Paper FP/49/E. FAO: Rome, Italy. http://www.fao.org/3/a-i5023e.pdf

Fujimoto, T.; Kobori, T.H.; Tsuchikawa, S. 2012. Prediction of wood density independently of moisture conditions using near infrared spectroscopy. J Near Infrared Spec 20(3): 353-359. https://www.osapublishing. org/jnirs/abstract.cfm?URI=jnirs-20-3-353

Gindl, W.; Teischinger, A.; Schwanninger, M.; Hinterstoisser, B. 2001. The relationship between near infrared spectra of radial wood surfaces and wood mechanical properties. J Near Infrared Spec 9(4): 255-261. https://www.osapublishing.org/jnirs/abstract.cfm?URI=jnirs-9-4-255

Haddadi, A.; Hans, G.; Leblon, B.; Pirouz, Z.; Tsuchikawa, S.; Nader, J.; Groves, K. 2016. Determination of optical parameters and moisture content of wood with visible-near infrared spectroscopy. $J$ Near Infrared Spec 24(6): 571-585. https://www.osapublishing.org/jnirs/abstract.cfm?URI=jnirs-24-6-571

Hein, P.R.G.; Campos, A.C.M.; Trugilho, P.F.; Limba, J.T.; Chaix, G. 2009a. Near infrared spectroscopy for estimating wood basic density in Eucalyptus urophylla and Eucalyptus grandis. Cerne 15(2): 133- 
141. http://www.cerne.ufla.br/site/index.php/CERNE/article/view/197

Hein, P.R.G.; Clair, B.; Brancheriau, L.; Chaix, G. 2010. Predicting microfibril angle in Eucalyptus wood from different wood faces and surface qualities using near infrared spectra. $J$ Near Infrared Spec 18(6): 455-464. https://www.osapublishing.org/jnirs/abstract.cfm?URI=jnirs-18-6-455

Hein, P.R.G.; Lima, J.T.; Chaix, G. 2009b. Robustness of models based on near infrared spectra to predict the basic density in Eucalyptus urophylla wood. J Near Infrared Spec 17(3): 141-150. https://doi.org/10.1255/jnirs.833

Hoffmeyer, P.; Pedersen, J.G. 1995. Evaluation of density and strength of Norway spruce wood by near infrared reflectance spectroscopy. Holz Roh Werkst 53:165-170. https://doi.org/10.1007/BF02716418

Kelley, S.S.; Rials, T.G.; Snell, R.; Groom, L.H.; Sluiter, A. 2004. Use of near infrared spectroscopy to measure the chemical and mechanical properties of solid wood. Wood Sci Technol 38(4): 257-276. https://doi.org/10.1007/s00226-003-0213-5

Kokutse, A.D.; Brancheriau L.; Chaix, G. 2010. Rapid prediction of shrinkage and fiber saturation point on teak (Tectona grandis) wood based on near-infrared spectroscopy. Ann For Sci 67: 403. https://doi.org/10.1051/forest/2009123

Kothiyal, V.; Raturi, A. 2011. Estimating mechanical properties and specific gravity for five-year-old Eucalyptus tereticornis having broad moisture content range by NIR spectroscopy. Holzforschung 65(5): 757 762. https://doi.org/10.1515/hf.2011.055

Leblon, B.; Adedipe, O.; Hans, G.; Haddadi, A.; Tsuchikawa, S.; Burger, J.; Stirling, R.; Pirouz, Z.; Groves, K.; Nader, J. 2013. A review of near-infrared spectroscopy for monitoring moisture content and density of solid wood. For Chron 89(5): 595-606. https://doi.org/10.5558/tfc2013-111

Michell, A.J.; Schimleck, L.R. 1996. NIR spectroscopy of woods from Eucalyptus globulus. Appita J 49(1): 23-26

Mora, C.R.; Schimleck, L.R. 2009. Determination of specific gravity of green Pinus taeda samples by near infrared spectroscopy: comparison of pre-processing method using multivariate figures of merit. Wood Sci Technol 43(5-6): 441-456. https://doi.org/10.1007/s00226-008-0235-0

Mora, C.R.; Schimleck, L.R.; Isik, F. 2008. Near infrared calibration models for the estimation of wood density in Pinus taeda using repeated sample measurements. J Near Infrared Spec 16(6): 517-528. https://doi.org/10.1255/jnirs.816

Naimeke, F.B.; Amusant, N.; Kadio, A.A.; Thevenon, M.F.; Nourissier, S.; Adima, A.A.; Allemand C.J.; Chaix, G. 2014. Rapid prediction of phenolic compounds as chemical markers for the natural durability of teak (Tectona grandis Linn f.) heartwood by near infrared spectroscopy. J Near Infrared Spectrosc 22(1): 35-43. https://www.osapublishing.org/jnirs/abstract.cfm?URI=jnirs-22-1-35

Pandey, D.; Brown, C. 2000. Teak: A Global Overview. Unasylva 51(201): 3-12. http://www.fao.org/3/ x4565e/x4565e03.htm\#P0_0

Prieto, N.; Pawluczyk, O.; Dugan, M.E.R.; Aalhus, J.L. 2017. A review of the principles and applications of near-infrared spectroscopy to characterize meat, fat, and meat products. Applied spectroscopy 71(7): 1403-1426. https://doi.org/10.1177/0003702817709299

Raturi, A.; Kothiyal, V.; Uniyal, K.K.; Semalty, P.D. 2012. Development and evaluation of models for specific gravity of Eucalyptus tereticornis wood by Fourier transformed near infrared spectroscopy and partial least squares regression analysis. J Ind Acad Wood Sci 9(1): 40-45. https://doi.org/10.1007/s13196-012-0069-0

Roggo, Y.; Chalus, P.; Maurer, L.; Lema-Martinez, C.; Edmond, A.; Jent, N. 2007. A review of near infrared spectroscopy and chemometrics in pharmaceutical technologies. J Pharmaceut Biomed 44(3): 683700. https://doi.org/10.1016/j.jpba.2007.03.023

Savitzky, A.; Golay, J.E. 1964. Soothing and differentiation of data by simplified least squares proce- 
dures. Anal Chem 36(8):1627-1639. https://doi.org/10.1021/ac60214a047

Schimleck, L.R.; Evans, R. 2002. Estimation of microfibril angle of increment cores by near infrared spectroscopy. IAWA J 23(3): 225-234. https://doi.org/10.1163/22941932-90000300

Schimleck, L.R.; Evans, R. 2003. Estimation of air-dry density of increment cores by near infrared spectroscopy. Appita J 56(4): 312-317. http://hdl.handle.net/102.100.100/193697?index=1

Schimleck, L.R.; Evans, R.; Ilic, J. 2001. Estimation of Eucalyptus delegatensis clear wood properties by near infrared spectroscopy. Can J Forest Res 31(10): 1671-1675. https://doi.org/10.1139/x01-101

Schimleck, L.R.; Mora, C.; Daniels, R.F. 2003. Estimation of the physical wood properties of green Pinus taeda radial samples by near infrared spectroscopy. Can J Forest Res 33(12): 2297-2305. https://doi.org/10.1139/x03-173

Schimleck, L.R.; Raymond, C.A.; Beadle, C.L.; Downes, G.M.; Kube, P.D.; French, J. 2000. Applications of NIR spectroscopy to forest research. Appita J 53(6): 458-464. http://hdl.handle.net/102.100.100/208650?index=1

Schwanninger, M.; Rodrigues, J.C.; Fackler, K. 2011. A review of band assignments in near infrared spectra of wood and wood components. J Near Infrared Spectrosc 19: 287-308. https://doi.org/10.1255/ jnirs.955

So, C.L.; Via, B.K.; Groom, L.H.; Schimleck, L.R.; Shupe, T.F.; Kelley, S.S.; Rials, T.G. 2004. Near infrared spectroscopy in the forest products industry. Forest Prod J 54(3): 6-16. https://www.srs.fs.usda.gov/ pubs/ja/ja_so001.pdf

Tewari, D.N. 1999. A Monograph on Teak (Tectona grandis Linn. f.). International Book Distributors: Dehra Dun, India. 479p.

Tsehaye, A.; Buchanan, A.; Meder, R.; Newman, R.; Walker, J. 1997. Microfibril angle: determining wood stiffness in radiate pine. In Microfibril Angle in Wood. Butterfield, B.G. (Ed.). International Association Wood Anatomists. University of Canterbury: Christchurch, New Zealand. p. 323-336.

Tsuchikawa, S.; Hirashima, Y.; Sasaki, Y.; Ando, K. 2005. Near infrared spectroscopic study of the physical and mechanical properties of wood with meso and microscale anatomical observation. Appl Spectrosc 59(1): 86-93. https://www.osapublishing.org/as/abstract.cfm?URI=as-59-1-86

Tsuchikawa, S.; Kobori, H. 2015. A review of recent application of near infrared spectroscopy to wood science and technology. J Wood Sci 61: 213-220. https://doi.org/10.1007/s10086-015-1467-x

Tsuchikawa, S.; Schwanninger, M. 2013. A review of recent near-infrared research for wood and paper. Applied Spectroscopy Reviews 48(7): 560-587. https://doi.org/10.1080/05704928.2011.621079

Tsuchikawa, S.; Siesler, H.W. 2003. Near-infrared spectroscopic monitoring of the diffusion process of deuterium-labeled molecules in wood. Part II: hardwood. Appl Spectrosc 57(6):675-681. https://doi.org/10.1366/000370203322005373

Via, B.K.; So, C.L.; Shupe, T.F.; Stine, M.; Groom, L.H. 2005. Ability of near infrared spectroscopy to monitor air-dry density distribution and variation of wood. Wood Fiber Sci 37(3): 394-402. https://wfs.swst.org/index.php/wfs/article/view/569/569

Williams, P.C. 2001. Implementation of near-infrared technology. In Near-Infrared Technology in the Agricultural and Food Industries. Williams, P; Norris, K (Eds.). $2^{\text {nd }}$ Edition. American Association of Cereal Chemists: St. Paul, MN, USA, 145-169 pp. 